DOI 10.15290/cnisk.2019.01.06.10

DR JULITA SITNIEWSKA

https://orcid.org/0000-0001-5511-3967

Wojewódzki Urząd Ochrony Zabytków w Białymstoku

\title{
Małgorzata Dajnowicz, Maria Bauchrowicz-Tocka, Wiesław Wróbel (red.), Słownik Biograficzny Kobiet Kultury. Białystok i województwo podlaskie, cz. II, (Białystok : Wydawnictwo Humanica, 2018), ss. 152. ISBN 978-83- 946177-1-4 (całość), 978-83-946177-6-9 (cz. II)
}

Słowniki biograficzne czy informatory poświęcone wyłącznie postaciom kobiecym zaczęły ukazywać się w Polsce po 1945 r., z różnym natężeniem wydawniczym. Pierwszy okres ich publikacji przypadł na czasy stalinowskie (lata 50. XX w.) i obfitował w propagandowe życiorysy kobiece. W kolejnym okresie, między 1958 a 1971 r., nie wydano ani jednej publikacji o tej tematyce, dopiero od 1985 r. po dzień dzisiejszy mamy do czynienia $z$ intensywnym upowszechnianiem biografii i biogramów kobiecych ${ }^{1}$. Większość tych dzieł dotyczy Polek. Biorąc pod uwagę zasięg terytorialny i chronologiczny słowników, można stwierdzić, że w większości omawianego tu typu publikacji, obejmujących czasy od starożytności po XIX w., pojawiają się bardzo szeroko lub dość enigmatycznie określone grupy kobiet: sławne, wpływowe, niepospolite, znane, nieznane, fatalne, namiętne itp. Drugi szeroki zestaw stanowią władczynie oraz żony lub faworyty władców i przywódców mające wpływ na poli-

1 Marta Skalska-Zlat, „Poświęcone kobietom słowniki i biografie zbiorowe wydane w Polsce od 1945 roku", w: Ewa Andrysiak (red.), Ludzie i ksiażki: studia i szkice bibliologiczno-bibliograficzne: ksiegga pamiątkowa dedykowana profesor Hannie Tadeusiewicz, (Łódź : Wydawnictwo Ibidem, 2011), 348-349. 
tykę. Wreszcie trzecia, ale znacznie mniej liczna grupę stanowią kobiety pobożne: święte i zakonnice. Te trzy kategorie kobiet pojawiają się także w informatorach obejmujacych XIX i XX w., ale już nie dominuja. W nich bowiem znajduja swoje miejsce kobiety wyraźnie określone zawodowo: pilotki, aktorki, biznesmenki, bibliotekarki, agentki wywiadu, alpinistki itd., a także kobiety - bohaterki II wojny światowej² ${ }^{2}$

Słownik Biograficzny Kobiet Kultury. Białystok i województwo podlaskie, cz. II jest unikatowy w przestrzeni herstorycznej, ponieważ wpisuje się w nurt lokalnego, regionalnego przewodnika po życiorysach kobiet, znanych i mniej znanych odbiorcom, które przeszły już do historii. Jest on następna częścia $z$ serii, opublikowaną w 2018 r. przez Wydawnictwo HUMANICA $z$ Białegostoku. Publikacja po raz kolejny została dofinansowana ze środków $z$ budżetu miasta Białegostoku, Wydziału Historyczno-Socjologicznego Uniwersytetu w Białymstoku i Instytutu Studiów Kobiecych. Autorami życiorysów Słownika Biograficznego sa: Małgorzata Dajnowicz (profesor Uniwersytetu w Białymstoku), Maria Bauchrowicz-Tocka (dziennikarka Tygodnika Podlaskiego „Kontakty”) oraz Wiesław Wróbel (historyk). Przedsięwzięcie owo ma na celu, jak pisze we wstępie do Słownika Biograficznego Małgorzata Dajnowicz, pomysłodawczyni publikacji, upowszechnianie wiedzy na temat kobiet, które

w mniejszym lub większym stopniu, były uczestniczkami życia kulturalnego społeczności, w których funkcjonowały, a poprzez swoja postawę i aktywność kształtowały ich oblicze kulturalne, wnosząc wkład w całokształt dorobku kulturowego miasta, regionu, kraju, a w przypadku niektórych kobiet przestrzeni międzynarodowej ${ }^{3}$.

W publikacji znalazło się 20 portretów bohaterek związanych z Białostocczyzna, Podlasiem, ziemią łomżyńską i Suwalszczyzną. Sa to w kolejności opisu i z podziałem na poszczególne ziemie - białostockie, podlaskie: Anna $z$ Radziwiłłów Kiszczyna $2^{\circ}$ v. Sadowska, Petronela z Radziwiłłów Dowojno, Katarzyna Scholastyka z Sapiehów Branicka, Maria Brock, Józefina Teofila Aleksandra z Zachertów Zachert, Berta z Schneiderów Szaykowska, Helena Frankiewicz; - łomżyńskie, Łomża: Wacława Lignowska, Justyna Budzińska-Tylicka, Zofia Chylińska-Le-

\footnotetext{
2 Ibidem, 353.

3 Małgorzata Dajnowicz, „Wstęp”, w: Małgorzata Dajnowicz, Maria Bauchrowicz-Tocka, Wiesław Wróbel (red.), Słownik Biograficzny Kobiet Kultury, Białystok i województwo podlaskie, cz. II, (Białystok : Wydawnictwo Humanica, 2018), 7.
} 
śmian, Maria Moczydłowska, Maria Rychter, Helena Filochowska, Tola Mankiewiczówna, Helena Czernek, Wiesława Szymańska; - Suwalszczyzna, Suwałki: Józefa Żdżarska, Kazimiera Żulińska, Julia Emilia Kunc, Aleksandra Piłsudska. Zamiarem pomysłodawczyni publikacji jest wyraźne spajanie biografii kobiecych działaczek $z$ wyżej wymienionych terenów, połączonych w $1998 \mathrm{r}$. w województwo podlaskie. We wstępie do publikacji podkreślono, że portrety kobiece sa pogrupowane chronologicznie odpowiednio według podziału terytorialnego trzech byłych województw: białostockiego, łomżyńskiego i suwalskiego, sprzed reformy administracyjnej 1998 r. Mimo przyjętego podziału terytorialnego bohaterki publikacji sa siostrzano podobne do siebie, ponieważ ich aktywności życiowej przyświecała chęć wykazania się poza rolą przypisywaną kulturowo kobiecie.

Oprócz funkcji upowszechniania wiedzy na temat znanych i mniej znanych bohaterek życia kulturalnego szerszemu obiegowi Słownik Biograficzny wpisuje się w publikacje, które przedstawiaja początki zmian $\mathrm{i}$ ich dokonywanie się w pełnionych przez kobiety rolach społecznych na przestrzeni wieków, wskazując na działanie tych postaci w sferze kultury będącej złożonym fenomenem, obejmującej wiele znaczeń i zakresów tematycznych ${ }^{4}$. Kultura to aktywność zwiazana z pojęciem „ducha”, obejmująca przestrzenie sztuki, religii, nauki, stająca się elementem wzbogacającym ludzką egzystencję ${ }^{5}$. Ma także znaczenie szersze. Traktując o zachowaniu i funkcjonowaniu człowieka w społeczeństwie, wskazuje na aktywność i wytwory ludzkie. W tym właśnie drugim aspekcie - aktywności i wytworów - Stownik Biograficzny zbiera wiedzę na temat szczególnych dla wyżej wymienionych ziem bohaterek - działaczek. Niektóre $z$ biografii moga być anonimowe dla badaczy historii kobiet. Część z nich żyje w przestrzeni dzięki świadectwom pisanym i przekazom ustnym. To dzięki tym materiałom można było dokonać analizy aktywności niektórych $z$ przedstawionych postaci, dotąd nieznanych szerszemu obiegowi. $Z$ zawartości materiałów źródłowych można wnioskować, że owe bohaterki były osobami oryginalnymi jak na swoje czasy, świadomymi swoich potrzeb i wychodzacymi poza ramy doświadczenia życia rodzinnego. Nie ograniczały się jedynie do przypisywanych im kulturowo ról społecznych czy aktywności polegających zazwyczaj na dbaniu o przysłowiowe

\footnotetext{
4 Joanna Hańderek, „Pojęcia i definicje kultury”, w: Piotr Mróz (red.), Filozofia kultury, (Kraków : Uniwersytet Jagielloński w Krakowie, 2015), 23.

5 Ibidem, 24-25.
} 
"ognisko domowe" bacḱ opiece nad najbliższymi, ale dotykały spraw gospodarstwa, majątku i osób z nim związanych, przechodząc do sfery edukacji, kultury oraz w inne przestrzenie życia. Słownik Biograficzny jest dla odbiorcy przewodnikiem herstorycznym tej części Polski.

W drugiej części Słownika Biograficznego mamy kontynuację redakcyjną opracowania tekstu części pierwszej. Każdy z życiorysów zawiera datacje życia bohaterek, słowa kluczowe w językach polskim i angielskim, krótkie streszczenie w języku angielskim oraz podsumowanie. Słownik zaopatrzony został w bibliografię i spis fotografii. Autorzy biografii korzystali z bogatej literatury krytycznej oraz ze źródeł rękopiśmiennych, drukowanych, pamiętników, artykułów prasowych, a także źródeł internetowych. Nakład 150 egzemplarzy jest niewspółmierny do wagi publikacji. Miejmy nadzieję, że w przyszłości będzie większy, aby mógł trafić do szerszego obiegu.

Poddając analizie spis treści części drugiej, znalazły się w nim bohaterki, jak wspomniano wyżej, które moga być nierozpoznawalne, anonimowe dla wielu czytelników. Małgorzata Dajnowicz we wstępie do słownika zwraca uwagę na występujące problemy $z$ dostępnością źródeł i literatury do przygotowania niektórych życiorysów. Praca nad opracowaniem ich w wielu wypadkach mogła być pionierska. Słownik stanowi nie tylko kompendium zbierające wiedzę na temat poszczególnych postaci kobiecych zaangażowanych już od XVI stulecia w życie kulturowe wyżej wymienionych ziem polskich, lecz także może stanowić dalszą inspiracje do pracy nad szerszymi opracowaniami dotyczącymi postaci. Słownik jest w wielu miejscach dziełem „odkrywajacym” nieznane sylwetki bohaterek, które $z$ różnych przyczyn ukrył czas, a pamięć o nich przetrwała albo w szczątkowych opisach źródłowych, albo w pamięci ludzkiej.

Część „Białystok, Podlasie” otwiera biografia Anny z Radziwiłłów Kiszczyny $2^{\circ}$ v. Sadowskiej (1525-1600), córki Jana Radziwiłła podczaszego litewskiego i Anny Kostewiecz (córki wojewody podlaskiego Janusza Kostewicza), będącej żoną Stanisława Kiszki, starosty brasławskiego, od 1544 r. wojewody witebskiego. Postać ta z perspektywy czasów wspó1czesnych zasługuje na uznanie i szersze opracowanie jej losów. Podjał się tego po części Jarosław Zawadzki, zamieszczając swój tekst w publikacji z 2005 r. Władza i prestiz. Magnateria Rzeczypospolitej $w$ XVI-XVIII $w$.

6 Lidia Marszałek, „Kulturowe uwarunkowania roli kobiety we współczesnym świecie”, Seminare. Poszukiwania naukowe, nr 25, 2008, 269. 
Anna $z$ Radziwiłłów była dobrze wykształcona, wychowaną w duchu reformacji arianka, która angażowała się w dysputy teologiczne. Jej działalność kulturalna przebiegała na równi $z$ działalnością administracyjna i gospodarcza. To ona przeprowadziła pomiar włócznej w swoich majątkach litewskich, stanowiącą wielką reformę agrarną, która rozpoczęła się na terenie Rzeczypospolitej w drugiej połowie XVI w. z inicjatywy królowej Bony i Zygmunta Starego.

Łomżyńską grupę portretów kobiecych inicjuje biografia ziemianki Wacławy Lignowskiej, urodzonej w 1863 r. Jej rodzina, tak jak wiele innych rodzin ziemiańskich, doświadczyła represji po udziale w powstaniu styczniowym. Majatek ojca został zarekwirowany, a ona jako małe dziecko wraz z matką była przez rok przetrzymywana w więzieniu grodzieńskim. Działalność Wacławy Lignowskiej zwiąana była $z$ oświata. Nie tylko uczyła dzieci z rodzin ziemiańskich, takich jak rodzina Lutosławskich z Drozdowa, lecz także młodzież z kółek oświatowych. Wiedzę o jej życiu oraz życiu rodziny Lutosławskich czerpiemy przede wszystkim $z$ jej pamiętników.

Część poświęconą Suwalszczyźnie otwiera Józefa Żdżarska (18391910), nauczycielka i pisarka. Jej członkowie rodziny - ojciec i siostra silnie byli zwiąani z nauczaniem. Bohaterka zapisała się na kartach historii przede wszystkim jako założycielka kilku pensji dla dziewcząt oraz pisarka i publicystka. To ona w piśmie „Tygodnik Ilustrowany” opisała Suwałki, w których się urodziła i mieszkała. Jest to unikatowa, jedna z najstarszych relacji przedstawiajacych życie miasta ${ }^{7}$.

Ostatnim życiorysem w Słowniku Biograficznym jest ten poświęcony Aleksandrze Piłsudskiej (1882-1963), suwalczance. Niewiele osób zna pochodzenie - korzenie drugiej żony Józefa Piłsudskiego. Jej biografia zamyka drugą część publikacji nie tylko pod względem chronologicznym, lecz także symbolicznym. Postać Aleksandry Piłsudskiej w 2018 r., w stuleciu odzyskania niepodległości przez państwo polskie, przypomina o kobietach, które były związane $z$ aktywnościa na rzecz suwerenności narodowej. Jej szczególna rola i doświadczenia okresu poprzedzającego uzyskanie wolności przez nasz kraj w 1918 r. stawiane są na równi z jej aktywnościa promotora sprawy polskiej w Londynie po II wojnie światowej.

7 Dwutygodnik Suwalski, 18.12.2019, [Dostęp: 25.05.2019]. Dostępny w World Wide Web: <https://bit.ly/349x3YN>. 
Biografia Aleksandry Piłsudskiej kończy tę część Słownika Biograficznego, ale nie zamyka serii publikacji. $Z$ niecierpliwościa oczekuje się na jego kolejne wydania, zadając pytanie o zawartość, a tym samym zastanawiając się, jakimi biografiami moga zaskoczyć nas redagujący następne części. Może znajda się w tych publikacjach także bohaterki żyjące, $z$ bagażem aktywności wypełniającym kilka życiorysów? To pytanie zostawiam otwarte.

\section{Bibliografia}

Dajnowicz, Małgorzata, Bauchrowicz-Tocka, Maria, Wróbel, Wiesław (red.). Stownik Biograficzny Kobiet Kultury. Bialystok i województwo podlaskie, cz. II, (Białystok : Wydawnictwo Humanica, 2018). ISBN 978-83-9461776-9.

Dwutygodnik Suwalski, 18.12.2019, [Dostęp: 25.05.2019]. Dostępny w World Wide Web: <https://bit.ly/349x3YN>.

Hańderek, Joanna. „Pojęcia i definicje kultury”, w: Piotr Mróz (red.), Filozofia kultury, (Kraków : Uniwersytet Jagielloński w Krakowie, 2015), 23-42.

Marszałek, Lidia. „Kulturowe uwarunkowania roli kobiety we współczesnym świecie", Seminare. Poszukiwania naukowe, $\mathrm{nr}$ 25, 2008, 267-279. ISSN 1232-8766.

Skalska-Zlat, Marta. „Poświęcone kobietom słowniki i biografie zbiorowe wydane w Polsce od 1945 roku", w: Ewa Andrysiak (red.), Ludzie i ksiażki: studia $i$ szkice bibliologiczno-bibliograficzne: ksiega pamiatkowa dedykowana profesor Hannie Tadeusiewicz, (Eódź : Wydawnictwo Ibidem, 2011), 347-364. ISBN 978-83-62331-12-3. 